\title{
Association between Chronic Kidney Disease and Sleep Duration among Jeju Farmers: Safety for Agricultural Injuries of Farmers Cohort Study
}

\author{
Miyeon Kim ${ }^{1}$, Sung Wook Song ${ }^{2,4}$, Jung-Hwan $\mathrm{Oh}^{3,4}$ \\ ${ }^{1}$ Departments of Internal Medicine, ${ }^{2}$ Emergency Medicine, and ${ }^{3}$ Neurology, Jeju National University College/School of Medicine, Jeju, \\ ${ }^{4}$ Center for Farmers' Safety and Health at Jeju National University Hospital, Jeju, Korea
}

\section{농업인에서 수면 시간과 만성콩팥병의 연관성에 대한 분석}

김미연 ${ }^{1}$, 송성욱 ${ }^{2,4}$, 오정환 ${ }^{3,4}$

제주대학교 의과대학/의학전문대학원 내과학교실, ${ }^{1}$ 응급의학교실, ${ }^{2}{ }^{~}$ 신경과학교실, ${ }^{3}$ 제주대학교병원 농업안전보건센터 ${ }^{4}$

Received November 8, 2019

Revised November 18, 2019

Accepted November 25, 2019

Address for correspondence Jung-Hwan Oh, MD Department of Neurology, Jeju National University College/School of Medicine, 15 Aran 13-gil, Jeju 63241, Korea Tel: +82-64-717-1620 Fax: +82-64-717-1620 E-mail:

oh.junghwan77@gmail.com
Objectives: This study was conducted to identify the association between sleep duration and chronic kidney disease (CKD) among the agriculture population. Methods: We utilized the study of Safety for Agricultural Injuries of Famers cohort collected from September 2015 to June 2018, which was data on the health and behaviors of the adult agriculture population on Jeju Island, South Korea. CKD was defined as estimated glomerular filtration rate $<60 \mathrm{~mL} / \mathrm{min} / 1.73 \mathrm{~m}^{2}$. Results: A total of 493 participants were included in the analysis, and $72(14.6 \%)$ of them were identified as diagnosed with CKD. There was a statistical difference in the prevalence of CKD among the subjects with $<6$ hours $(24.1 \%), 6$ to 8 hours $(8.4 \%)$ and $\geq 8$ hours $(18.2 \%)$ of daily average sleep duration $(p<0.001)$. Multivariable analyses revealed that daily average sleep duration of $<6$ hours [odds ratio $(\mathrm{OR})=3.79, p=0.007$ ] and $\geq 8$ hours $(\mathrm{OR}=3.39, p=0.009)$ were significantly associated with CKD compared to 6 to 8 hours of the duration. Conclusions: Our findings suggest that both shorter and longer sleep duration give a higher risk of having $\mathrm{CKD}$ among the agriculture population. Adequate sleep within 6 to 8 hours a day can help prevent CKD in the agriculture population.

J Sleep Med 2019;16(2):95-101

Key Words: Sleep, Chronic kidney diseases, Farmers.

\section{서 론}

만성콩팥병의 유병률은 전 세계에서 8 16\%에 달하며, 2013 년 질병관리본부에서 발표한 우리나라 만성콩팥병의 유병률 은 만 30 세 이상에서 $4.1 \%, 65$ 세 이상에서 $16.5 \%$ 로 보고되었 으며 실제로는 더 많을 것으로 여겨진다. ${ }^{1}$ 우리나라의 고령화 가 급속도로 진행하면서 다른 만성 질환과 함께 만성콩팥병의 유병률은 더 증가될 것으로 판단되고, 만성콩팥병 인구의 증 가는 다른 만성 질환에 비해 사회 경제 비용의 부담이 크다. ${ }^{2,3}$

최근 15 개 연구를 바탕으로 한 메타 분석연구에 따르면 농

This is an Open Access article distributed under the terms of the Creative Commons Attribution Non-Commercial License (https://creativecommons.org/licenses/by-nc/4.0) which permits unrestricted non-commercial use, distribution, and reproduction in any medium, provided the original work is properly cited.
업인이 일반인보다 만성콩팥병 유병률이 더 높았다는 점에 서 볼 때, ${ }^{4}$ 농업인들에서 만성콩팥병의 이환과 악화를 예방하 기 위한 위험인자를 조기에 확인하고 이에 대한 적극적인 개 선이 필요하다.

수면 시간은 신진대사 조절 및 삶의 질 향상에 중요한 요인 이고, 일부 인구 기반 연구에서 짧거나 긴 수면 시간은 심혈 관계 질환 및 이 질환의 위험인자와 관련이 있었다. ${ }^{5-9}$ 비만, 당뇨병, 고혈압과 같은 심혈관계 질환 위험인자들은 만성콩 팥병의 위험 요인이기도 하다. 따라서 수면 시간은 만성콩팥 병과도 연관이 있을 수 있다는 추측이 가능하고, 실제 적절 한 수면 시간은 콩팥 기능 유지에 도움을 준다는 연구들도 있다. ${ }^{10-13}$

저자들은 제주도 농업 인구를 대상으로 수행된 전향적 코 
호트 연구에서 수집된 정보를 바탕으로 수면 시간과 만성콩 팥병의 관련성을 규명하고자 본 연구를 시행하였다.

\section{방 법}

\section{대 상}

본 연구는 2015년부터 2018년까지 시행된 제주대학교병원 농업안전보건센터의 농업인 작업 손상 코호트(Safety for Agricultural Injuries of Farmers cohort study, SAIF)에 등록 된 대상자를 이용하였다. 제주 지역 농가는 38,502호(2014년) 이며, 농업 인구는 111,745 명(제주 전체 인구의 $18.5 \%$ ) 규모 이다. SAIF 조사 모집단은 제주도 농업 작목 현황 및 지역적 특색에 대한 고찰과 현지 실사를 수행한 후, 축산업을 포함 한 농작목 종류와 의료 시설에 대한 거리 접근성에 따라 층 화 선정되었고, 조사 시점 2주 내 발생한 농작업 관련 손상 경험이 없는 농업인으로 하였다. 이들 중 연구에 참여하기로 동의를 한 대상자에게 대면설문조사와 검진조사(혈액검사, 신체 측정)를 매해 분기별로 2 번씩 총 4 회 수행하여 농업 활 동이나 개인 사정으로 인한 조사 참여 누락을 최소화하였다. 설문조사 항목 선정을 위해 농작업 관련 손상조사를 포함해 서 포괄적으로 설문 항목을 고찰하였고, 주요 위험인자 및 취 약 요인의 인과관계 확인을 위해 필요한 조사 항목이 연구 진 및 관련 전문가의 자문회의를 거쳐서 결정되었다. 선정된 조사 항목에 대한 평가를 위해 현장에서 이용 가능한 대면설 문조사 표준 기록지를 개발하였다. 코호트 대면설문조사 소 요 시간은 평균 30 분이었다.

총 17 개 조사 지역에 거주하는 농업인 964명에 대해서 대 면설문조사를 완료하였고, 이 중 503명에 대해서는 신체 계 측, 혈액검사 및 영상검사를 포함한 검진 조사를 완료하였다. 이 중에서 추정 사구체 여과율(estimated glomerular filtration rate, eGFR)을 계산하기 위해 혈청 크레아티닌 검사가 가능 했던 총 493명의 자료를 분석하였다. 본 연구는 제주대학교 병원 기관생명윤리심의위원회(Institutional Review Board, IRB)의 심의를 거쳐 승인을 받았다(JNUH IRB No. 201911-009).

\section{연구 도구}

SAIF 설문조사는 인구학적 정보 및 가구 조사 등 일반적 특성, 건강 행태, 건강 상태, 농작업 행태 및 작업 손상 경험 등에 대한 항목으로 구성되었다. 일반적 특성에는 나이, 성 별, 학력, 혼인 여부, 소득 수준 등의 요소가 포함되었다. 학 력은 분석을 위해 초졸 이하, 중졸 이하, 고졸 이하, 초대졸 이상의 4 개 그룹으로 분류하였고, 소득 수준에 대해서는 연
소득 1,500 만원 이하, 1,500 만원에서 2,900 만원, 3,000 만원에 서 5,900만원 및 60,000 만원 이상의 그룹으로 분류하였다. 건강 행태에 대한 항목에는 "하루에 평균 몇 시간 수면을 취 하십니까?”라는 질문을 통해 수면 시간을 정량적으로 평가하 였고, 주당 운동 횟수, 흡연 여부, 한 달간 음주 횟수 등도 평 가하였다. 건강 상태 항목에 대해서는 고혈압, 당뇨, 이상지 질혈증, 갑상선 질환, 뇌졸중, 심근경색 등의 심혈관계 질환 및 암 등의 유병 여부를 확인하였고, 주관적인 건강 상태도 나쁨, 보통, 좋음의 세 군으로 평가하였다. 농작업 관련 세부 항목으로는 농업 유형을 곡물 재배, 과수 재배, 채소 재배, 축 산업 및 기타 농업 등 5 개로 분류하였고, 고용 형태도 자영농, 고용직 농업군 등으로 분류하여 평가하였다. 하루 평균 농작 업 시간(1시간 미만, 1 2시간, 2 3시간, 3 4시간, 4시간 이 상) 및 농약 살포 방법(직접 살포, 살포 보조, 직접 살포 또는 살포 보조, 농약 살포하지 않음) 또한 평가하였다.

검진 조사에는 의학 검진 문진표, 신체 계측, 활력 징후, 혈 액검사(일반혈액검사, 혈액응고검사, 생화학검사, 호르몬검 사)가 포함되어 있었다. 콩팥 기능을 평가하기 위해 생화학 검사의 혈청 크레아티닌 수치를 Modification Diet in Renal Disease formula[186 $\times(\text { serum creatinine/88.4 })^{-1.154} \times(\text { age })^{-0.203}$ $\times\left(0.742\right.$ if female)]에 대입하여 $\mathrm{eGFR}$ 을 계산하였다. ${ }^{14} \mathrm{eGFR}$ 이 $60 \mathrm{~mL} / \mathrm{min} / 1.73 \mathrm{~m}^{2}$ 미만인 경우 2012년 the Kidney Disease: Improving Global Outcomes 진단기준에 따라 만성콩 팥병이 있는 것으로 간주하였다. ${ }^{15}$

\section{분석 방법}

설문 및 검진 조사 자료의 변수 특성에 따라 빈도와 백분 율, 평균과 표준편차로 제시하였다. 하루 평균 수면 시간에 따른 세 군(6시간 미만, 6 시간 이상 8시간 미만, 8시간 이상) 으로 분류하였고, 이 군들 간에 연속형 변수는 일원분산분석 을, 범주형 변수는 카이제곱 검정 또는 피셔의 정확 검정 (Fisher's exact test)을 이용하여 분석하였다. 사후 분석은 Bonferoni 방법을 이용하여 각 군 간의 유의성을 서로 비교 하였다. eGFR로 측정한 콩팥 기능과 수면 시간을 비롯한 여 러 변수들과의 연관성을 확인하기 위해 로지스틱 회귀 분석 을 통해 단변량 및 다변량 분석을 시행하였고, 단변량 분석 에서 $p<0.100$ 의 변수들을 이용하여 다변량 분석을 시행하 였다. 분석은 SPSS 20.0(IBM Corp., Armonk, NY, USA) 프 로그램을 이용하였고, $p<0.050$ 인 경우 유의한 통계적 차이 가 있는 것으로 판정하였다. 


\section{결 과}

\section{수면 시간에 따른 대상자의 일반적 특성}

연구에 선정된 대상자 493명의 기본 특성은 Table 1에 제 시되어 있다. 하루 평균 수면 시간은 $6.5 \pm 1.5$ 시간(1 14시간) 이었다. 이들의 평균 연령은 59.8土11.4세(27 84세)였고, 하 루 평균 수면 시간에 따라 세 군(6시간 미만, 6시간 이상 8시 간 미만, 8 시간 이상)으로 분류하였을 때 세 군 간에 유의한 차이를 보였고, 수면 시간 6시간 이상 8시간 미만 군이 6시간 미만 군보다 더 유의하게 나이가 적었다 $(p=0.021)$. 대상자 수 는 남성이 여성보다 더 많았지만, 수면 시간에 따른 성비의 차 이는 없었다. 평균 $\mathrm{eGFR}$ 은 $72.6 \mathrm{~mL} / \mathrm{min} / 1.73 \mathrm{~m}^{2}$ 로 세 군 간 에 차이를 보였고, 사후 분석 결과 하루 평균 수면 시간이 6시 간 이상 8시간 미만의 군이 6시간 미만 군보다 통계적으로 유 의하게 높았다 $(p=0.001)$. 대상자 중 만성콩팥병으로 진단된 경우는 총 72 명(14.6\%)이었고, 이 또한 세 군 간에 유의한 차 이를 보였다 $(p<0.001)$. 하루 평균 작업 시간 및 학력은 세 군 에서 유의한 차이는 있었지만, 고용 형태 $(p=0.163)$, 혼인 여부 $(p=0.221)$, 우울증 진단 여부 $(p=0.127)$ 를 포함하여 그 밖의 다 른 변수들에서는 통계적으로 의미 있는 차이를 보이지 않았다.

\section{단변량 및 다변량 분석 결과}

단변량 분석 결과 하루 평균 수면 시간은 만성콩팥병과 통 계적인 유의한 차이가 있었다(Supplementary Table 1 in the online-only Data Supplement). 하루 평균 수면 시간이 6시 간 이상 8 시간 미만인 군보다, 6시간 미만인 군[odds ratio $(\mathrm{OR})=3.44,95 \%$ confidence interval $(\mathrm{CI})=1.85-6.42, p<$ $0.001]$ 및 8 시간 이상인 군 $(\mathrm{OR}=2.41,95 \% \mathrm{CI}=1.28-4.50, p=$ 0.006)에서 만성콩팥병 유병의 통계적인 차이를 보였다. 이 외에도 나이, 학력, 연간 소득, 주관적 건강 상태, 한 달간 음 주 횟수 및 심혈관계 질환, 고혈압, 당뇨병, 이상지질혈증의 병력도 만성콩팥병과 연관성이 있었다(Supplementary Table 1 in the online-only Data Supplement). 다변량 분석법 으로 $p<0.100$ 의 변수들을 이용하여 다중로지스틱 회귀 분 석을 시행하였다(Table 2). 나이, 하루 평균 수면 시간, 학력, 연간 소득, 주관적 건강 상태, 음주 상태 및 심혈관계 질환, 고혈압, 당뇨병, 이상지질혈증의 병력 중 만성콩팥병에 유의 한 영향을 미치는 변수는 나이 $(\mathrm{OR}=1.09,95 \% \mathrm{CI}=1.04-1.14$, $p<0.001)$ 와 하루 평균 수면 시간 $(p=0.009)$ 이었는데, 하루 평 균 수면 시간이 6시간 미만인 군 $(\mathrm{OR}=3.79,95 \% \mathrm{CI}=1.43-$ $10.03, p=0.007)$ 과 8 시간 이상인 군 $(\mathrm{OR}=3.39,95 \% \mathrm{CI}=1.35-$ $8.53, p=0.009$ )에서 6시간 이상 8시간 미만인 군보다 만성콩 팥병이 더 많이 발생됨을 확인할 수 있었다.

\section{고 찰}

본 연구는 농업인 대상의 전향적 코호트 연구로 저자들은 농업인의 수면 시간이 하루 6시간 이상에서 8시간 미만보다 적거나 많을 때, 만성콩팥병이 3 4배 더 빈번함을 확인할 수 있었다.

최근 들어 저자들의 연구와 비슷한 결과를 보인 인구 기반 연구들이 있었다. 2019년에 타이완 19만여 명의 성인 코호트 에서 수면 시간 및 수면의 질과 만성콩팥병의 관계를 본 연 구가 보고되었다. ${ }^{12}$ 이 연구 결과에서 하루 평균 6 시간 이상 8시간 미만 수면을 취하는 군보다 4시간 미만, 4시간 이상 6 시간 미만 및 8시간 이상의 수면을 취하는 군에서 각각 만성 콩팥병 발생의 위험이 각각 $45 \%, 7 \%$ 및 $12 \%$ 증가되었다. 중 국에서 발표된 3만3천 명의 중년의 성인을 대상으로 시행된 관찰 연구에서 단백뇨는 수면 시간이 길수록 위험률이 올라 갔으나, 수면 시간과 사구체 여과율은 U형의 연관관계를 보 였다. ${ }^{11}$ 우리나라에서도 2011년부터 2014년까지 국민건강영 양조사에 등록된 2 만 명의 성인을 대상으로 했던 연구가 있 었는데, 7 시간을 기준으로 너무 길거나 짧은 수면이 높은 요 알부민 배설과 관련이 있었다. ${ }^{13}$

아직까지 수면 시간과 만성콩팥병의 관계를 설명하는 기 전에 대해서는 명확히 밝혀지지 않았지만, 교감신경계 활성 화에 의한 만성적인 염증에 따른 사구체 내피세포 손상이 가 설로 제시되고 있다. ${ }^{13,16}$

농업인들에서 비농업인들보다 만성콩팥병이 유병률이 높 다는 보고가 있으며, ${ }^{4}$ 특히 일반인들에서 만성콩팥병의 위험 인자로 알려진 당뇨병, 고혈압 등이 없는 경우에도 만성콩팥 병이 생기는 경우가 많다. 농업인에서 만성콩팥병이 많이 생 기는 원인에 대해서는 아직까지 밝혀진 바가 없지만, 열에 대 한 노출, 탈수, 농약이나 중금속에 대한 노출, 음주, 흡연 및 비스테로이드 소염제를 비롯한 진통제 복용 등이 위험인자 로 추정되고 있다. ${ }^{17}$ 본 연구에서 대상 집단의 평균 나이가 59.8 세로 고령 집단이었고, 만성콩팥병의 유병률은 $14.6 \%$ 로 나와, 이전 일반인 대상 연구에서 보였던 유병률과 큰 차이 는 없었다. ${ }^{1}$ 앞서 언급한 농업인에서 만성콩팥병의 원인으로 추정되는 요인들을 모두 분석할 수는 없었지만, 단변량 분석 에서 열에 대한 노출이나 탈수와 연관이 있을 것으로 생각 되는 평균 농작업 시간, 농약 노출과 연관이 있을 가능성이 있는 농약 살포 방법, 흡연 등의 인자는 만성콩팥병의 유병과 연관이 없었다(Supplementary Table 1 in the online-only Data Supplement). 또한 다변량 분석 결과 수면 시간은 만성 콩팥병과 유의한 연관을 보였지만, 월간 음주 횟수 $(p=0.136)$ 는 만성콩팥병과 통계적인 유의성을 보이지 않았고, 만성콩 
Table 1. Baseline characteristics

\begin{tabular}{|c|c|c|c|c|c|}
\hline \multirow[b]{2}{*}{ Variable } & \multirow{2}{*}{$\begin{array}{l}\text { Overall } \\
(n=493)\end{array}$} & \multicolumn{4}{|c|}{ Average sleep duration per day } \\
\hline & & $\begin{array}{c}<6 \mathrm{~h} \\
(\mathrm{n}=112)\end{array}$ & $\begin{array}{c}6 \text { to }<8 \text { h } \\
(n=249)\end{array}$ & $\begin{array}{c}\geq 8 \mathrm{~h} \\
(\mathrm{n}=132)\end{array}$ & $p$ \\
\hline $\mathrm{eGFR}, \mathrm{mL} / \mathrm{min} / 1.73 \mathrm{~m}^{2}$ & $72.6 \pm 15.0$ & $68.4 \pm 15.4$ & $74.6 \pm 14.3$ & $72.4 \pm 15.4$ & 0.001 \\
\hline CKD $\left(\mathrm{eGFR}<60 \mathrm{~mL} / \mathrm{min} / 1.73 \mathrm{~m}^{2}\right)(\%)$ & $72(14.6)$ & $27(24.1)$ & $21(8.4)$ & $24(18.2)$ & $<0.001$ \\
\hline Sex, female (\%) & $151(30.6)$ & $38(33.9)$ & $70(28.1)$ & $43(32.6)$ & 0.460 \\
\hline Age, year & $59.8 \pm 11.4$ & $63.0 \pm 11.6$ & $58.1 \pm 10.8$ & $60.4 \pm 11.7$ & 0.021 \\
\hline SBP, mm Hg & $130.8 \pm 14.1$ & $130.0 \pm 14.5$ & $131.5 \pm 14.2$ & $130.2 \pm 13.4$ & 0.342 \\
\hline $\mathrm{BMI}, \mathrm{kg} / \mathrm{m}^{2}$ & $25.7 \pm 3.5$ & $25.7 \pm 3.7$ & $25.9 \pm 3.7$ & $25.5 \pm 3.2$ & 0.277 \\
\hline Average sleep duration, $\mathrm{h}$ & $6.5 \pm 1.5$ & $4.5 \pm 0.9$ & $6.5 \pm 0.5$ & $8.4 \pm 0.8$ & $<0.001$ \\
\hline Agriculture types (\%) & & & & & 0.434 \\
\hline Crop cultivation & $68(13.8)$ & $18(16.1)$ & $35(14.1)$ & $15(11.4)$ & \\
\hline Fruit production & $234(47.5)$ & $44(39.3)$ & $125(50.2)$ & $65(49.2)$ & \\
\hline Vegetable production & $160(32.5)$ & $41(36.6)$ & $78(31.3)$ & $41(31.1)$ & \\
\hline Livestock production & $25(5.1)$ & $7(6.2)$ & $8(3.2)$ & $10(7.6)$ & \\
\hline Others & $6(1.2)$ & $2(1.8)$ & $3(1.2)$ & $1(0.8)$ & \\
\hline Average working time per day (\%) & & & & & 0.045 \\
\hline$<1 \mathrm{~h}$ & $21(4.3)$ & $11(9.8)$ & $7(2.8)$ & $3(2.3)$ & \\
\hline $1-2 \mathrm{~h}$ & $64(13.0)$ & $13(11.6)$ & $29(11.7)$ & $22(16.7)$ & \\
\hline $2-3 \mathrm{~h}$ & $99(20.1)$ & $19(17.0)$ & $56(22.7)$ & $24(18.2)$ & \\
\hline $3-4 \mathrm{~h}$ & $108(21.9)$ & $19(17.0)$ & $53(21.5)$ & $36(27.3)$ & \\
\hline$>4 \mathrm{~h}$ & $183(37.1)$ & $45(40.2)$ & $94(38.1)$ & $44(33.3)$ & \\
\hline Non-responders & $18(3.6)$ & $5(4.5)$ & $8(3.2)$ & $3(2.3)$ & \\
\hline Education level (\%) & & & & & $<0.001$ \\
\hline Elementary school or less & $114(23.1)$ & $43(38.4)$ & $44(17.7)$ & $27(20.5)$ & \\
\hline Middle school & $75(15.2)$ & $17(15.2)$ & $37(14.9)$ & $21(15.9)$ & \\
\hline High school & $191(38.7)$ & $40(35.7)$ & $94(37.8)$ & $57(43.2)$ & \\
\hline College or more & $113(22.9)$ & $12(10.7)$ & $74(29.7)$ & $27(20.5)$ & \\
\hline Yearly income level, Korean Won, million (\%) & & & & & 0.146 \\
\hline$<15$ & $97(19.7)$ & $30(26.8)$ & $45(18.1)$ & $22(16.7)$ & \\
\hline $15-29$ & $100(20.3)$ & $22(19.6)$ & $49(19.7)$ & $29(22.0)$ & \\
\hline $30-59$ & $103(20.9)$ & $15(13.4)$ & $62(24.9)$ & $26(19.7)$ & \\
\hline$\geq 60$ & $193(39.1)$ & $45(40.2)$ & $93(37.3)$ & $55(41.7)$ & \\
\hline Exercise times per week (\%) & & & & & 0.315 \\
\hline None & $345(70.0)$ & $83(74.1)$ & $164(65.9)$ & $98(74.2)$ & \\
\hline 1-3 times & $65(13.2)$ & $13(11.6)$ & $36(14.5)$ & $16(12.1)$ & \\
\hline 4-7 times & $80(16.2)$ & $15(13.4)$ & $48(19.3)$ & $17(12.9)$ & \\
\hline Non-responders & $3(0.6)$ & $1(0.9)$ & $1(0.4)$ & $1(0.8)$ & \\
\hline Subjective health status (\%) & & & & & 0.266 \\
\hline Poor & $129(26.2)$ & $38(33.9)$ & $59(23.7)$ & $32(24.2)$ & \\
\hline Average & $188(38.1)$ & $38(33.9)$ & $95(38.2)$ & $55(41.7)$ & \\
\hline Good & $176(35.7)$ & $36(32.1)$ & $95(38.2)$ & $45(34.1)$ & \\
\hline
\end{tabular}


Kim M et al.

Table 1. Baseline characteristics (continued)

\begin{tabular}{|c|c|c|c|c|c|}
\hline \multirow[b]{2}{*}{ Variable } & \multirow{2}{*}{$\begin{array}{l}\text { Overall } \\
(n=493)\end{array}$} & \multicolumn{4}{|c|}{ Average sleep duration per day } \\
\hline & & $\begin{array}{c}<6 \mathrm{~h} \\
(\mathrm{n}=112)\end{array}$ & $\begin{array}{l}6 \text { to }<8 \mathrm{~h} \\
(\mathrm{n}=249)\end{array}$ & $\begin{array}{c}\geq 8 \mathrm{~h} \\
(\mathrm{n}=132)\end{array}$ & $p$ \\
\hline Pesticide spraying (\%) & & & & & 0.933 \\
\hline Self-spraying & $364(73.8)$ & $84(75.0)$ & $185(74.3)$ & $95(72.0)$ & \\
\hline Spreader assistant & $59(12.0)$ & $14(12.5)$ & $27(10.8)$ & $18(13.6)$ & \\
\hline Self-spraying or assistant & $28(5.7)$ & $5(4.5)$ & $17(6.8)$ & $6(4.5)$ & \\
\hline No spraying & $8(1.6)$ & $2(1.8)$ & $4(1.6)$ & $2(1.5)$ & \\
\hline Non-responders & $34(6.9)$ & $7(6.2)$ & $16(6.4)$ & $11(8.3)$ & \\
\hline Alcohol intake per month (\%) & & & & & 0.065 \\
\hline No alcohol intake & $67(13.6)$ & $21(18.8)$ & $30(12.0)$ & $16(12.1)$ & \\
\hline 1 time or less & $84(17.0)$ & $16(14.3)$ & $45(18.1)$ & $23(17.4)$ & \\
\hline $2-4$ times & $70(14.2)$ & $10(8.9)$ & $37(14.9)$ & $23(17.4)$ & \\
\hline 5 times or more & $168(34.1)$ & $26(23.2)$ & $103(41.4)$ & $39(29.5)$ & \\
\hline Non-responders & $104(21.1)$ & $39(34.8)$ & $34(13.7)$ & $31(23.5)$ & \\
\hline Smoking (\%) & & & & & 0.245 \\
\hline Never & $230(46.7)$ & $59(52.7)$ & $108(43.4)$ & $63(47.7)$ & \\
\hline Former or current & $262(53.1)$ & $53(47.3)$ & $141(56.6)$ & $68(51.5)$ & \\
\hline Non-responders & $1(0.2)$ & $0(0.0)$ & $0(0.0)$ & $1(0.8)$ & \\
\hline Cardiovascular disease (\%) & & & & & 0.187 \\
\hline No & $454(92.1)$ & $99(88.4)$ & $234(94.0)$ & $121(91.7)$ & \\
\hline Yes & $39(7.9)$ & $13(11.6)$ & $15(6.0)$ & $11(8.3)$ & \\
\hline Hypertension (\%) & & & & & 0.416 \\
\hline No & $327(66.3)$ & $72(64.3)$ & $172(69.1)$ & $83(62.9)$ & \\
\hline Yes & $166(33.7)$ & $40(35.7)$ & $77(30.9)$ & $49(37.1)$ & \\
\hline Diabetes (\%) & & & & & 0.068 \\
\hline No & $420(85.2)$ & $88(78.6)$ & $217(87.1)$ & $115(87.1)$ & \\
\hline Yes & $72(14.6)$ & $24(21.4)$ & $31(12.4)$ & $17(12.9)$ & \\
\hline Non-responders & $1(0.2)$ & $0(0.0)$ & $1(0.4)$ & $0(0.0)$ & \\
\hline Hyperlipidemia (\%) & & & & & 0.677 \\
\hline No & $421(85.4)$ & $95(84.8)$ & $210(84.3)$ & $116(87.9)$ & \\
\hline Yes & $71(14.4)$ & $17(15.2)$ & $38(15.3)$ & $16(12.1)$ & \\
\hline Non-responders & $1(0.2)$ & $0(0.0)$ & $1(0.4)$ & $0(0.0)$ & \\
\hline Thyroid disease (\%) & & & & & 0.945 \\
\hline No & 463 (93.9) & $105(93.8)$ & $233(93.6)$ & $125(94.7)$ & \\
\hline Yes & $28(5.7)$ & $6(5.4)$ & $15(6.0)$ & $7(5.3)$ & \\
\hline Non-responders & $2(0.4)$ & $1(0.9)$ & $1(0.4)$ & $0(0.0)$ & \\
\hline Cancer (\%) & & & & & 0.300 \\
\hline No & $366(74.2)$ & $82(73.2)$ & $184(73.9)$ & $100(75.8)$ & \\
\hline Yes & $28(5.7)$ & $9(8.0)$ & $10(4.0)$ & $9(6.8)$ & \\
\hline Non-responders & $99(20.1)$ & $21(18.8)$ & $55(22.1)$ & $23(17.4)$ & \\
\hline
\end{tabular}

Data are $\mathrm{n}(\%)$ or mean \pm standard deviation values. eGFR: estimated glomerular filtration rate, CKD: chronic kidney disease, SBP: systolic blood pressure, BMI: body mass index 
Table 2. Multivariable analyses for relationship between CKD and sleep duration

\begin{tabular}{|c|c|c|c|c|}
\hline & $\mathrm{CKD}, \mathrm{n}(\%)$ & $\mathrm{OR}^{*}$ & $95 \% \mathrm{CI}$ & $p$ \\
\hline Average sleep duration per day & & & & 0.009 \\
\hline$<6 \mathrm{~h}(\mathrm{n}=112)$ & $27(24.1)$ & 3.79 & $1.43-10.03$ & 0.007 \\
\hline 6 to $<8 \mathrm{~h}(\mathrm{n}=249)$ & $21(8.4)$ & Reference & & \\
\hline$\geq 8 \mathrm{~h}(\mathrm{n}=132)$ & $24(18.2)$ & 3.39 & $1.35-8.53$ & 0.009 \\
\hline
\end{tabular}

*adjusted for age, education level, yearly income level, subjective health status, alcohol intake, cardiovascular diseases, hypertension, diabetes, and hyperlipidemia. CKD: chronic kidney disease, OR: odds ratio, CI: confidence interval

팥병의 위험인자로 알려진 당뇨병 $(p=0.142)$ 이나 고혈압 $(p=$ $0.200)$ 등의 질환과도 연관성은 없었다.

멜라토닌은 일주기 리듬의 표지자로 알려져 있고 정상인 에서는 수면 시작과 더불어 증가하는 양상을 보인다. 하지만 말기 콩팥병 환자에서는 이러한 현상이 나타나지 않음을 보 고한 연구가 있었고, ${ }^{11}$ 이 연구에서 말기 콩팥부전 환자는 4 6시간 정도의 짧고 분절된 수면을 경험하며, 1,2 단계 수 면은 길고, 서파수면은 짧아지는 양상을 보이고, 멜라토닌 분 비의 진폭과 주기가 콩팥 기능과 함께 저하되는 결과를 보였 다. ${ }^{11}$ 농업인의 수면 패턴에 관한 연구는 거의 없는 실정으로 저자들은 단지 한 개의 연구만을 찾을 수 있었는데, 이는 마 다가스카르의 농업인 21명의 수면다원검사 결과를 분석한 연구였다. ${ }^{8}$ 이 연구에서 서양 선진국의 인구와 비교했을 때 수면 시간이 짧았고, 수면 분절이 특징적이어서 위의 만성콩 팥병 환자들과 유사한 수면 패턴을 보였다. 따라서 농업인에 서 만성콩팥병의 아직까지 알려지지 않은 원인으로 수면 시 간도 포함될 수 있겠다.

저자들은 수면 시간과 만성콩팥병의 관련성을 처음으로 농업인에서 분석하였고, 농업인들에서 수면 시간과 만성콩 팥병은 밀접한 연관이 있다는 결론을 얻었다. 하지만 본 연구 에는 몇 가지 제한점이 있다. 첫째, 농업인의 특성상 대상군 의 나이가 많았다. 나이가 들수록 불면증, 폐쇄수면무호흡, 하지불안증후군 등 수면 질환의 유병률은 증가되고 이러한 질환들이 수면 시간의 변화를 가져올 수 있다. ${ }^{19}$ 또한 이러한 수면 질환은 일반인보다 만성콩팥병 환자에서 더 호발하는 것으로 알려져 있는데, 본 연구에서는 아쉽게도 이를 평가하 지 못하였다. ${ }^{20-22}$ 둘째, 이 연구는 수면의 양에 대해서만 분석 이 되었는데, 수면의 질, 낮잠 등도 만성콩팥병과 연관이 있 다는 보고들이 있고, ${ }^{10,11}$ 수면 시간보다 수면의 질이 만성콩팥 병과 관련이 있다는 연구도 있었다. ${ }^{10}$ 따라서 수면 시간과 만 성콩팥병의 연관성을 더 잘 구현하기 위해 수면 질환 동반 여부, 수면 행태 및 수면의 질적 지표를 통한 다변량 분석이 요구된다. 셋째, 만성콩팥병 진단에 $\mathrm{eGFR}$ 수치가 가장 중요 하지만, 콩팥 손상을 반영하는 요단백을 평가할 수 없어 본 연구에서 진단된 만성콩팥병 환자 수가 과소평가되었을 수
있다. 또한 액티그래피나 수면다원검사를 통해 객관적으로 수면 시간을 분석하지 못하였다. 하지만 많은 수의 대상자에 게 이를 적용시키는 것은 시간 및 비용 측면에서 현실적인 어 려움이 있을 수밖에 없다.

일반인보다 농업인에서 만성콩팥병은 빈번하다고 알려져 있고, 이들에게서 하루 6시간에서 8시간 이내의 적절한 수면 을 취하는 것이 만성콩팥병 예방에 도움을 줄 수 있겠다. 향 후 수면의 양적 지표인 수면 시간뿐 아니라, 수면의 질적 지 표를 비롯한 수면 행태나 수면질환 여부 등도 함께 분석하여, 농업인에서 수면 시간과 만성콩팥병 간의 인과성을 규명하 기 위한 체계적인 연구가 필요할 것이다.

\section{Supplementary Materials}

The online-only Data Supplement is available with this article at https:// doi.org/10.13078/jsm.190041.

\section{Acknowledgments}

We greatly appreciate to the members of the Center for Farmer Safety \& Health, Jeju National University Hospital.

\section{Conflicts of Interest}

The authors have no potential conflicts of interest to disclose.

\section{ORCID iDs}

$\begin{array}{ll}\text { Miyeon Kim } & \text { https://orcid.org/0000-0002-0020-3292 } \\ \text { Sung Wook Song } & \text { https://orcid.org/0000-0002-7056-6179 } \\ \text { Jung-Hwan Oh } & \text { https://orcid.org/0000-0003-3997-3267 }\end{array}$

\section{Author Contributions}

Conceptualization: Miyeon Kim, Jung-Hwan Oh. Data curation: Sung Wook Song, Jung-Hwan Oh. Formal analysis: Jung-Hwan Oh. Methodology: Miyeon Kim, Jung-Hwan Oh. Project administration: Sung Wook Song. Software: Jung-Hwan Oh, Sung Wook Song. Supervision: JungHwan Oh. Validation: Sung Wook Song. Visualization: Miyeon Kim, JungHwan Oh. Writing_original draft: Miyeon Kim. Writing_review \& editing: Jung-Hwan Oh.

\section{REFERENCES}

1. Park JI, Baek H, Jung HH. Prevalence of chronic kidney disease in Korea: the Korean National Health and Nutritional Examination Survey 2011-2013. J Korean Med Sci 2016;31:915-923.

2. Yoo KB, Choi JW, Kim BS, Kim TH. Socioeconomic burden of chronic kidney disease in south Korea. Korean Public Health Research 2014; 40:13-23. 
3. Jin DC. Current status of dialysis therapy for ESRD patients in Korea. $J$ Korean Med Assoc 2013;56:562-568.

4. Chapman E, Haby MM, Illanes E, Sanchez-Viamonte J, Elias V, Reveiz L. Risk factors for chronic kidney disease of non-traditional causes: a systematic review. Rev Panam Salud Publica 2019;43:e35.

5. Cappuccio FP, Taggart FM, Kandala NB, et al. Meta-analysis of short sleep duration and obesity in children and adults. Sleep 2008;31:619626.

6. Cappuccio FP, D’Elia L, Strazzullo P, Miller MA. Quantity and quality of sleep and incidence of type 2 diabetes: a systematic review and meta-analysis. Diabetes Care 2010;33:414-420.

7. Gangwisch JE, Heymsfield SB, Boden-Albala B, et al. Short sleep duration as a risk factor for hypertension: analyses of the first National Health and Nutrition Examination Survey. Hypertension 2006;47:833839.

8. Cappuccio FP, Cooper D, D’Elia L, Strazzullo P, Miller MA. Sleep duration predicts cardiovascular outcomes: a systematic review and meta-analysis of prospective studies. Eur Heart J 2011;32:1484-1492.

9. Wolff B, Völzke H, Schwahn C, Robinson D, Kessler C, John U. Relation of self-reported sleep duration with carotid intima-media thickness in a general population sample. Atherosclerosis 2008;196:727-732.

10. Li J, Huang Z, Hou J, et al. Sleep and CKD in Chinese adults: a crosssectional study. Clin J Am Soc Nephrol 2017;12:885-892.

11. Ye Y, Zhang L, Yan W, et al. Self-reported sleep duration and daytime napping are associated with renal hyperfiltration and microalbuminuria in an apparently healthy Chinese population. PLoS One 2019;14: e0214776.

12. Bo Y, Yeoh EK, Guo C, et al. Sleep and the risk of chronic kidney disease: a cohort study. J Clin Sleep Med 2019;15:393-400.

13. Yu JH, Han K, Kim NH, et al. U-shaped association between sleep du- ration and urinary albumin excretion in Korean adults: 2011-2014 Korea National Health and Nutrition Examination Survey. PLoS One 2018;13:e0192980.

14. Levey AS, Bosch JP, Lewis JB, Greene T, Rogers N, Roth D. A more accurate method to estimate glomerular filtration rate from serum creatinine: a new prediction equation. Modification of Diet in Renal Disease Study Group. Ann Intern Med 1999;130:461-470.

15. Stevens PE, Levin A; Kidney Disease: Improving Global Outcomes Chronic Kidney Disease Guideline Development Work Group Members. Evaluation and management of chronic kidney disease: synopsis of the kidney disease: improving global outcomes 2012 clinical practice guideline. Ann Intern Med 2013;158:825-830.

16. Maung SC, Sara AE, Chapman C, Cohen D, Cukor D. Sleep disorders and chronic kidney disease. World J Nephrol 2016;5:224-232.

17. Violo L, De Francesco M, Locatelli F. Chronic kidney disease of unknown cause in agricultural communities. N Engl J Med 2019;381:688689.

18. Samson DR, Manus MB, Krystal AD, Fakir E, Yu JJ, Nunn CL. Segmented sleep in a nonelectric, small-scale agricultural society in Madagascar. Am J Hum Biol 2017;29:e22979.

19. Miner B, Kryger MH. Sleep in the aging population. Sleep Med Clin 2017;12:31-38

20. Adeseun GA, Rosas SE. The impact of obstructive sleep apnea on chronic kidney disease. Curr Hypertens Rep 2010;12:378-383.

21. Lee J, Nicholl DM, Ahmed SB, et al. The prevalence of restless legs syndrome across the full spectrum of kidney disease. J Clin Sleep Med 2013;9:455-459.

22. Nigam G, Camacho M, Chang ET, Riaz M. Exploring sleep disorders in patients with chronic kidney disease. Nat Sci Sleep 2018;10:35-43. 